\title{
THE ROAD TOWARDS \\ THE HARMONISATION OF TRADE SECRETS \\ LAW IN THE EUROPEAN UNION
}

\author{
Paul L. C. Torremans*
}

\section{Starting points}

Traditionally, trade secret protection has been left to the national laws of the Member States. In part, this was due to the very varied approaches. Only recently has there been a trend towards (minimal) harmonisation at the level of the European Union. There are also provisions in the international treaties that are relevant, but again these provisions have a rather narrow (harmonising) scope.

In practice trade secrets have been gaining importance though. They are no longer seen mainly as the addendum to patent law and they have gained much more value and importance in their own right. Stories of (electronic) industrial espionage have only re-enforced the (perceived) need to protect trade secrets adequately. All this has brought about renewed attention for the topic of harmonisation of trade secrets law in the European Union. Previously, this was seen as difficult and in comparison not sufficiently important. The new draft directive now symbolises the renewed push towards harmonisation.

\section{National LAWS - TRADitional APPROACHES}

Defining exactly what amounts to a trade secret is not an easy task and there is no widely accepted definition of a trade secret. It is also important to note right from the start that the vast majority of countries in the EU offer a remedy in this

* Prof. Dr. Paul L.C. Torremans (Lic. Jur.) (Lic. Not.) (Geaggreg. Hso Rechten) (LLM) $(\mathrm{PhD})$, is Professor of Intellectual Property Law in the School of Law, University of Notitngham (Uk), Paul.Torremans@Nottingham.ac.uk Professor of Intellectual Property Law, School of Law, University of Nottingham (UK). Fecha de recepción: 3 de octubre de 2015. Fecha de aceptación: 15 de octubre de 2015. Para citar el artículo: Torremans, P. L. C. The road towards the harmonisation of trade secrets law in the European Union. Revista La Propiedad Inmaterial n. ${ }^{\circ}$ 20, Universidad Externado de Colombia, julio-diciembre 2015, pp. 27-38. DOI: http://dx.doi.org/10.18601/16571959.n20.02 
area, rather than an (exclusive) right. Italy is the most notable exception, as the Italian intellectual property code specifically lists trade secrets as an intellectual property right. ${ }^{1}$ Sweden has ad hoc legislation on trade secrets and Portugal and France (the latter only for manufacturing trade secrets) have specific provisions on the protection of trade secrets in their respective codes of intellectual property. ${ }^{2}$ Most other countries rely strongly on unfair competition law to offer a remedy for the abuse of trade secrets. Austria, Belgium, Germany, Poland and Spain are good examples. ${ }^{3}$ Yet other countries, such as the Netherlands and Luxemburg, rely on general principles of tort law to offer a remedy. On the common law side there is a strong reliance on breach of confidence, e.g. in the United Kingdom ${ }^{4}$ and in Ireland, but also in Malta. ${ }^{5}$

All countries also rely strongly on contract law. Often there is also a (somewhat more limited) role for criminal law. Belgian law is a good example. Whereas trade secrets in general are protected by the law of unfair competition and the law of contract, there is special protection in criminal law for the more restrictive category of trade secrets known as manufacturing trade secrets. ${ }^{6}$

\section{National laws rather than a Directive or a Regulation}

What has become clear from these introductory comparative comments is that not only is there no exclusive right, leaving Italy to one side for a moment, but only a remedy based on different legal principles, there is also no Eu instrument dealing with trade secrets. At present there is no harmonisation Directive or a Community trade secret based on a Regulation. De lege lata the whole matter is left with the individual member states. As we will see though, that may change in the near future (de lege feranda). ${ }^{7}$

1. Articles 98 and 99 of the Italian Industrial Property Code.

2. Study on Trade Secrets and Confidential Business Information in the Internal Market, Final Study. April 2013, Prepared for the European Commission http://ec.europa.eu/ internal_market/iprenforcement/docs/trade-secrets/130711_final-study_en.pdf

3. See Van Caeneghem, W., Trade secrets and intellectual property: Breach of confidence, misappropriation and unfair competition, Wolters Kluwer, 2014.

4. P. Torremans, Holyoak and Torremans Intellectual Property Law, $7^{\text {th }}$ ed., oup, 2013, Ch 29.

5. T. Aplin, L. Bently, Ph. Johnson \& S. Malynicz, Gurry on breach of confidence: The protection of confidential information, oup, 2nd ed., 2012.

6. Study on Trade Secrets and Confidential Business Information in the Internal Market, Final Study. April 2013, Prepared for the European Commission http://ec.europa.eu/ internal_market/iprenforcement/docs/trade-secrets/130711_final-study_en.pdf

7. See P. Torremans, Holyoak and Torremans Intellectual Property Law, $7^{\text {th }}$ ed., oup, 2013, p. 623. 


\section{The Paris Convention and the trips Agreement}

There are however some international foundations on which this area of law and the various approaches in the Member States are built. Article 10bis of the Paris Convention obliges the Member States to provide effective protection and unfair competition. The appropriation of trade secrets without permission is probably one of the clearest examples of acts of unfair competition and, as was seen above, Article 10bis and the reliance on principles of unfair competition is reflected in the national laws of many Member States. Section 7 of the TRIPs Agreement then builds on this starting point and article 39 TRIPs Agreement deals explicitly with the protection of undisclosed information. As all Eu Member States are bound by the TRIPs Agreement and in the absence of an EU instrument dealing with trade secrets, the following provision is the common core of the national approaches to trade secret protection:

SECTION 7: PROTECTION OF UNDISCLOSED INFORMATION

\section{Article 39}

1. In the course of ensuring effective protection against unfair competition as provided in Article 10bis of the Paris Convention (1967), Members shall protect undisclosed information in accordance with paragraph 2 and data submitted to governments or governmental agencies in accordance with paragraph 3.

2. Natural and legal persons shall have the possibility of preventing information lawfully within their control from being disclosed to, acquired by, or used by others without their consent in a manner contrary to honest commercial practices so long as such information:

(a) is secret in the sense that it is not, as a body or in the precise configuration and assembly of its components, generally known among or readily accessible to persons within the circles that normally deal with the kind of information in question;

(b) has commercial value because it is secret; and

(c) has been subject to reasonable steps under the circumstances, by the person lawfully in control of the information, to keep it secret.

3. Members, when requiring, as a condition of approving the marketing of pharmaceutical or of agricultural chemical products which utilize new chemical entities, the submission of undisclosed test or other data, the origination of which involves a 
considerable effort, shall protect such data against unfair commercial use. In addition, Members shall protect such data against disclosure, except where necessary to protect the public, or unless steps are taken to ensure that the data are protected against unfair commercial use.

Note: For the purpose of this provision, "a manner contrary to honest commercial practices" shall mean at least practices such as breach of contract, breach of confidence and inducement to breach, and includes the acquisition of undisclosed information by third parties who knew, or were grossly negligent in failing to know, that such practices were involved in the acquisition.

A first important point in this article is the definition that is offered of the concept of undisclosed information. That definition falls apart into three requirements. First of all, protection is, or should be, available if the information is secret. That is in turn defined as information that is not generally known among or readily accessible to persons within the circles that normally deal with the kind of information in question. Availability of the information in the public domain seems to be the bottom line here. Secondly, on top of that the aspect of secrecy must give or add commercial value to the information. And thirdly, the person lawfully in control of the information must take reasonable steps to keep it secret. ${ }^{8}$

The importance of this definition is for example also shown by the fact that the Italian intellectual property code has copied it quasi verbatim when defining its trade secret right.

Whilst the focus is clearly on secrecy and the confidential nature of the information, there is virtually no restriction, apart from the element of 'commercial value', on the kind of information that can be protected. In practice a diverse range of information is covered. Technical knowledge, often referred to in this context as know-how, is the obvious example, but all kinds of commercial data such as information on customers and suppliers, business plans, market strategies and market research are also included in the range of information that can be protected as a trade secret. ${ }^{9}$

A second important point is the indication that is given as to what kind of dealings with trade secrets will entitle their holder to a remedy. Or if one want to put it this way, what will amount to an act of unfair competition or when will a tort be committed in relation to a trade secret? On this point article 39 TRIPs Agreement places the emphasis on the unauthorised disclosure by, acquisition to or use by others without the consent of the holder of the undisclosed information

8. D. Gervais, The Trips Agreement: Drafting history and analysis, $4^{\text {th }}$ ed., Sweet $\&$ Maxwell, 2012, pp. 541-546.

9. See A. Coleman, The legal protection of trade secrets, Sweet \& Maxwell, 1992. 
in a manner contrary to honest commercial practices. The concepts of disclosure, acquisition or use without the consent of the holder of the undisclosed information are rather straightforward and do not require additional clarification. The qualification to these things happen in a manner contrary to honest commercial practices is interesting though and goes beyond a mere reference to unfair competition. The note to article 39 explains that for the purpose of that provision, "a manner contrary to honest commercial practices" shall mean at least practices such as breach of contract, breach of confidence and inducement to breach, and includes the acquisition of undisclosed information by third parties who knew, or were grossly negligent in failing to know, that such practices were involved in the acquisition. Especially the reference to third parties who know or who were grossly negligent in failing to know brings in a subjective element. There is on the other hand a strong tendency to keep this element to an objective test. Obliging the claimant to prove a subjective element in the mind of the defendant makes effective trade secret protection more burdensome and harder to achieve. There may not be a right in the information that forms the trade secret, but applying merely an objective test makes obtaining protection easier and seems to be more aligned to the practice in relation to intellectual property rights. ${ }^{10} \mathrm{We}$ will return to this debate later on in this chapter in the context of the proposed Eu Directive. Suffice it to say here that the Commission proposal included a subjective element, clearly based in the wording of article 39 TRIPs Agreement and the note to it, whilst the Council prefers an objective test.

\section{The Draft Directive}

\section{A minimalist approach is proposed}

Pushed to an extent by allegations of large scale espionage by the us, the European Commission proposed a 'Directive on the protection of undisclosed know-how and business information (trade secrets) against their unlawful acquisition, use and disclosure' in November 2013. ${ }^{11}$ The Council has now issued its opinion (19 May 2014) ${ }^{12}$ on the draft Directive, but the European Parliament is still debating the draft. There is therefore not yet a European instrument in this area, let alone one that has been implemented by the Member States, but the eu is clearly edging towards a degree or harmonisation when it comes to the protection of trade secrets.

10. D. Gervais, The Trips Agreement: Drafting history and analysis, $4^{\text {th }}$ ed., Sweet $\&$ Maxwell, 2012, pp. 541-546.

11. See http://ec.europa.eu/internal_market/iprenforcement/docs/trade-secrets/131128_ proposal_en.pdf

12. See http://register.consilium.europa.eu/doc/srv?l=EN\&f=ST\%209870\%202014\%20 INIT 
One should emphasise right from the start that this is a very different endeavour than e.g. the Trade Mark Directive. The aim is not to put in place a comprehensive Eu regime for the protection of trade secrets. There will only be a partial harmonisation of the national laws of the Member States, focussing on the unlawful acquisition, disclosure and use of trade secrets, and that harmonisation will be of a minimalist nature in the sense that Member States may provide, in compliance with the provisions of the Treaty, for more far-reaching protection against the unlawful acquisition, use or disclosure of trade secrets than that required in the Directive. The Council thought it wise to add that expressis verbis to article 1 of the draft Directive. Whilst businesses will be able to rely on a minimal level of protection for the their trade secrets in every Member State, they will still have to contend with 28 (slightly) different national laws routed in different areas of law. The benefits of this harmonisation will therefore be much more limited that the benefits in other areas of intellectual property law, such as trade marks, design, and even copyright.

\section{Definitions}

The Directive does of course need a definition of a trade secret. In this respect the draft sticks closely to article 39 TRIPs Agreement. This is the version of article 2 of the draft Directive:

For the purposes of this Directive, the following definitions shall apply:

(1) 'trade secret' means information which meets all of the following requirements:

(a) is secret in the sense that it is not, as a body or in the precise configuration and assembly of its components, generally known among or readily accessible to persons within the circles that normally deal with the kind of information in question;

(b) has commercial value because it is secret;

(c) has been subject to reasonable steps under the circumstances, by the person lawfully in control of the information, to keep it secret;

(2) 'trade secret holder' means any natural or legal person lawfully controlling a trade secret;

(3) 'infringer' means any natural or legal person who has unlawfully acquired, used or disclosed trade secrets; 
(4) 'infringing goods' means goods whose design, quality, functioning, manufacturing process or marketing significantly benefits from trade secrets unlawfully acquired, used or disclosed.

Whilst it is the generally accepted definition, it should not be forgotten that this definition is very wide in scope and covers an immense variety of technical and commercial information.

\section{The scope of unlawful acquisition, use ANd Disclosure}

Article 3 then turns to the crux of the matter and defines the scope of violation of a trade secret. Redress is provided for the unlawful acquisition, use or disclosure of a trade secret. The key concept here is that the relevant activity must be unlawful. In the Commission's proposal proving unlawfulness involved passing a threshold of intention or (at least) gross negligence. This subjective element might raise the burden of proof and is out of line with the traditional approach towards primary infringement of intellectual property. The Council therefore proposed to replace it with a more objective approach that holds that any acquisition, use or disclosure which is, under the circumstances, considered contrary to honest commercial practices will be unlawful. This is also a return to the text of article 39 TRIPs Agreement, whereas the Commission had taken over the language of the final sentence of the note to that article. Knowledge as a factor is then restricted to forms of violation that can be characterised as indirect or secondary. In the Council's version this results in the following provision:

2. The acquisition of a trade secret without the consent of the trade secret holder shall be considered unlawful, whenever carried out by [...] unauthorised access to, copying or appropriation of any documents, objects, materials, substances or electronic files, lawfully under the control of the trade secret holder, containing the trade secret or from which the trade secret can be deduced [or] any other conduct which, under the circumstances, is considered contrary to honest commercial practices.

3. The use or disclosure of a trade secret shall be considered unlawful whenever carried out, without the consent of the trade secret holder by a person who is found to meet any of the following conditions:

(a) have acquired the trade secret unlawfully;

(b) be in breach of a confidentiality agreement or any other duty to not disclose the trade secret; 
(c) be in breach of a contractual or any other duty to limit the use of the trade secret.

4. The acquisition, use or disclosure of a trade secret shall also be considered unlawful whenever a person, at the time of acquisition, use or disclosure, knew or should, under the circumstances, have known that the trade secret was obtained directly or indirectly from another person who was using or disclosing the trade secret unlawfully within the meaning of paragraph 3.

5. The production, offering or placing on the market of infringing goods, or import, export or storage of infringing goods for those purposes, shall also be considered an unlawful use of a trade secret when the person carrying out such activities knew, or should, under the circumstances, have known that the trade secret was used unlawfully within the meaning of paragraph 3 .

This provision gives the protection of trade secrets an extremely wide scope. ${ }^{13}$ And in certain circumstances such a wide scope of protection will not be appropriate and could trample on other rights. Article 4 tries to address that problem by putting in place a number of limitations. In a first step the article holds the acquisition of trade secrets to be lawful if it is achieved by independent discovery or creation; through observation, study, disassembly or test of a product or object that has been made available to the public or that it is lawfully in the possession of the acquirer of the information who is free from any legally valid duty to limit the acquisition of the trade secret; or any other practice which, under the circumstances, is in conformity with honest commercial practices. In all these circumstances there is no real obligation of secrecy and definitively no breach any such obligation. There is in other words no clash or conflict with the protection of the trade secret. In a second step the article has however to deal with those circumstances where there is a real clash with other rights or interests. One thinks here of the freedom of expression of investigative journalists, whistleblowers, workers representatives, etc. The Council has made this distinction very clear by adding a sentence that inserts the principle that any acquisition, use or disclosure of a trade secret will be lawful to the extent that it is required or allowed, not merely by Eu law, but also by the national law of the member state concerned. The reference to national law should not simply be seen as a sign of weak harmonisation. National law still governs major issues in our society where trade secrets could potentially interfere with other rights and interests, e.g. in relation to criminal justice, press regulation or certain elements of labour law and the representation of workers in companies. It is therefore important to

13. Compare in the current uk system: P. Torremans, Holyoak and Torremans Intellectual Property Law, $7^{\text {th }}$ ed., oup, 2013, Ch. 29. 
state clearly that the Directive will not overrule those other legal provisions. The final paragraph of article 4 illustrates that principle by ruling out any remedy for any alleged acquisition, use or disclosure of a trade secret that was carried out:

(a) for making legitimate use of the right to freedom of expression and information;

(b) for the purpose of revealing a misconduct, wrongdoing or illegal activity, provided that the alleged acquisition, use or disclosure of the trade secret was necessary for such revelation and that the respondent acted in the public interest;

the trade secret was disclosed by workers to their representatives as part of the legitimate exercise of their representative functions, provided that such disclosure was necessary for that exercise; $[\ldots]$

(e) for the purpose of protecting a legitimate interest recognised by Union or national law.

One should not underestimate the importance of article 4. There was a clear need to protect other rights and interest, not all of which are in areas of (exclusive) EU competence. The version of the article suggested by the Council goes a long way in getting the balance between the interest of the holder of the trade secret on the one hand and the various other rights and interests that count in our society right. The remainder of the effort lies with the Member States and the courts when they will implement and apply the Directive. ${ }^{14}$

\section{Redress}

The draft Directive provides various form of redress, but the Commission's draft and, even more explicitly through the insertion of the word 'civil' in article 5, the Council's draft make it very clear that the draft Directive is only concerned with civil redress. Criminal law is not affected, which, in combination with the minimalist approach of the draft Directive, also means that those national laws that do have criminal sanctions, e.g. for the violation of manufacturing trade secrets, will be allowed to retain these or to introduce additional criminal sanctions. The measures, procedures and remedies that the Member States put in place by way of civil redress need to meet the general standards of fairness, equitableness, effectiveness and dissuasiveness and need not be unnecessarily complicated or 
costly, nor entail unreasonable time-limits or unwarranted delays. This approach has been copied from the TRIPs Agreement and the Enforcement Directive. Similarly, any application of such measures, procedures and remedies needs to be proportionate and provide safeguards against their abuse. There will also be a limitation period for claims based on the Directive's provisions, but whereas the Commission wants to work with a very short period of one to two years after the holder of the trade secret becomes aware of the breach, the Council prefers to leave this to the Member States and to impose merely a maximum limitation period of six years. Both approaches reflect the perceived need to deal quickly with these matters and to remove any uncertainty in the interest of all parties involved.

Legal proceedings concerning a trade secret and its allegedly illegal acquisition, use or disclosure are of course in themselves a risk for the disclosure of a trade secret. It is therefore important that those involved in the proceedings can be given an obligation not to disclose the trade secret. That is what the Commission's draft did in its article 8. The Council's draft takes a more cautious approach and requires a reasoned application by the interested party to install a secrecy regime in relation to information that the competent authorities have identified as confidential. However one deals with it, confidentiality of trade secrets in the course of proceedings is in certain cases necessary and a vital ingredient of any regime dealing with trade secrets.

Just as with many other intellectual property, time is often of the essence. Secrecy is something that cannot be restored once it has been broken, making fast measures to prevent the acquisition, use or disclosure of a trade secret vital. Once a violation has occurred it is vital to stem the breach and to avoid that the consequences of the violation of the trade secret causes irreparable or large scale damage. The draft Directive addresses these concerns in its article 9 by putting in place a system of interim and precautionary measures. The holder of a trade secret can apply to the court for an interim injunction that prohibits or orders the cessation of the use or the disclosure of the trade secret on an interim basis. The holder can also apply for interim measures that deal with allegedly infringing goods. These measure can take the format of an order prohibiting the production, offering or placing on the market of the allegedly infringing goods, their importation, exportation or storage for these purposes. Allegedly infringing goods can also be seized or their delivery up can be ordered to prevent their entry into the market or their circulation within the market. ${ }^{15}$

Once a decision on the merits has been reached and the acquisition, use or disclosure of the trade secret has been held to be unlawful the Draft Directive provides a range of possible measures in its article 11. At the top of the list of

15. Compare P. Torremans, Holyoak and Torremans Intellectual Property Law, $7^{\text {th }}$ ed., oup, 2013, Ch. 32 . 
measures one finds injunctions, essentially to order the cessation or prohibition of the use of the disclosure of the trade secret. A prohibition to produce, offer, place on the market or use infringing goods that have benefitted from the trade secret in any way, or import, export or store such infringing goods for those purposes may also be granted by the court by way of injunctive relief. On top of that the draft Directive proposes corrective measures with regard to the infringing goods. These infringing goods can be recalled from the market ${ }^{16}$ or there infringing quality can be removed. The court can also order the destruction of the infringing goods or the destruction of all or part of any document, object, material, substance or electronic file containing or implementing the trade secret or, where appropriate, the delivery up to the applicant of all or part of those documents, objects, materials, substances and electronic files.

In addition damages can be awarded, either damages that are commensurate to the actual prejudice suffered or damages as a lump sum (e.g. on the basis of an estimate of royalties that could have become payable for the lawful use of the trade secret). The courts can also order the publication of the judgment. ${ }^{17}$

\section{Conclusion}

Trade secrets play an important role in our modern economy and business environment. In the form of know-how they do not only form an alternative to patent protection for an invention, but even if a patent is granted there is complimentary know-how, e.g. concerning the best way to exploit the patent, that is not included in the patent application. That know-how is then kept and protected as a trade secret. But also outside the area of technical information there are all kinds of elements of commercial information, e.g. about the market and (potential) clients that are not available to the public domain at large, but that have great value, in part due to their confidential nature.

In the absence of an intellectual property right that protects the trade secret, national laws have longstanding tradition of protecting the trade secrets by offering a remedy against its unlawful acquisition, use or disclosure. These national regimes are rooted firmly in existing legal rules in the areas of unfair competition, tort or breach of confidence. But there is diversity, rather than uniformity. The only uniform provisions de lege lata are found in the basic provisions of the Paris Convention and the TRIPs Agreement.

16. The holder of the trade secret can also request that the infringing goods are delivered up to it or to charitable organisations.

17. See T. Aplin, "A critical evaluation of the proposed Eu Trade Secrets Directive", King's College London Law School Research Paper n. ${ }^{\circ}$ 2014-25, http://papers.ssrn.com/sol3/ papers.cfm?abstract_id=2467946 
The eu draft Directive that is currently under consideration proposes to change that by imposing on Member States a minimal form of harmonisation and uniformity. It would not impose a (Community) right in relation to a trade secret, but it works with a common basic definition of a trade secret, the principle that there needs to be redress for the unlawful acquisition, use or disclosure of a trade secret and an catalogue of measures and remedies. Its aims are therefore limited, but its adoption would mean some progress in this area.

\section{BiBLIOGRAPHY}

Aplin, T., "A Critical Evaluation of the Proposed eu Trade Secrets Directive", King's College London Law School Research Paper n. ${ }^{\circ}$ 2014-25, http://papers. ssrn.com/sol3/papers.cfm?abstract_id $=2467946$

Aplin, T.; Bently, L., Johnson, Ph. \& Malynicz, S., Gurry on breach of confidence: The protection of confidential information, $2^{\text {nd }}$ ed., oup, 2012.

Coleman, A., The legal protection of trade secrets, Sweet \& Maxwell, 1992.

Gervais, D., The Trips Agreement: Drafting history and analysis, $4^{\text {th }}$ ed., Sweet $\&$ Maxwell, 2012.

Study on Trade Secrets and Confidential Business Information in the Internal Market, Final Study, April 2013, Prepared for the European Commission http:// ec.europa.eu/internal_market/iprenforcement/docs/trade-secrets/130711_ final-study_en.pdf

Torremans, P., Holyoak and Torremans Intellectual Property Law, $7^{\text {th }}$ ed., oup, 2013. Van Caeneghem, W., Trade secrets and intellectual property: Breach of confidence, misappropriation and unfair competition, Wolters Kluwer, 2014. 